TOBA (Journal of Tourism, Hospitality and Destination)
journal.literasisains.id/index.php/TOBA
ISSN Media Elektronik 2828-4100
Vol. 1 No. 1 (Februari 2022) 07-13
DOI: https://doi.org/10.55123/toba.v1i1.78

\title{
Pengembangan Tata Kelola Destinasi Pariwisata Melalui Pendekatan Pemberdayaan Masyarakat di Kampung Wisata Braga
}

\author{
Rifqi Asy'ari ${ }^{* 1}$, Lia Afriza ${ }^{2}$, Agnes Tresia Silalahi ${ }^{3}$ \\ Institut Teknologi Sumatera ${ }^{* 1,3}$ \\ Sekolah Tinggi Ilmu Ekonomi Pariwisata Yapari Bandung ${ }^{2}$ \\ e-mail: rifqi.asyari@pwk.itera.ac.id*1, lia.afriza@gmail.com², agnes.silalahi@pwk.itera.ac.id³
}

\begin{abstract}
ABSTRAK
Pemerintah Kota Bandung mencanangkan kampung kreatif di 30 kecamatan di Kota Bandung. Pengembangan pariwisata yang ada dalam tata kelola destinasi kampung wisata di Kota Bandung dapat dibentuk sebagai kampung wisata tematik dengan atribut penting yang mengintegrasikan potensi wisata yang ada di kampung wisata. Salah satunya Kampung Wisata yang diusung dalam pengembangan yaitu Kampung Wisata Braga melalui pendekatan pemberdayaan masyarakat. Kampung Wisata Braga yang menjadi fokus pengembangan pariwisata dalam bentuk pemberdayaan masyarakat yang dilakukan Dinas Kebudayaan dan Pariwisata Kota Bandung menjadi langkah yang dilakukan dalam penyusunan tata kelola destinasi pariwisata di Kota Bandung pada tahun 2020 melalui dana alokasi khusus. Metode yang dipergunakan yaitu metode survei dengan pendekatan kualitatif melalui teknik pemberdayaan masyarakat sebagai tujuan pengabdian kepada masyarakat di kampung wisata. Temuan yang didapat dari pengabdian masyarakat yang terjadi dari tata kelola destinasi di Kota Bandung khususnya di Kampung Wisata Braga dari hasil yang ada yaitu pengelolaan, fasilitas dan regulasi menjadi hambatan yang terjadi dalam pengembangan yang dilakukan di Kampung Wisata Braga. Kampung Wisata Braga memiliki keunikan dan ikon yang kuat melekat dengan Kota Bandung yang dikenal dengan Bandung Heritage yang memiliki sejarah dan dikenal sebagai kota konferensi Asia Afrika. Hasil pemberdayaan masyarakat yang dilakukan menyebutkan bahwa pengembangan tata kelola destinasi pariwisata yang dapat dikembangkan di Kampung Wisata Braga dengan mengintegrasi potensi wisata yang terdapat di Kelurahan Braga berupa kegiatan utama yang ada yaitu berkeliling mengunjungi warisan budaya dan mengenal sejarah.
\end{abstract}

Kata kunci : Kampung Wisata; Pemberdayaan Masyarakat; Pengembangan Pariwisata

\section{ABSTRACT}

The Bandung City Government has launched creative villages in 30 sub-districts in Bandung City. The tourism development that is in the management of tourist village destinations in Bandung City can be formed as a thematic tourism village with important attributes that integrate the tourism potential that exists in the tourist village. One of them is the Tourism Village which is carried out in development, namely the Braga Tourism Village through a community empowerment approach. Kampung Wisata Braga is the focus of tourism development in the form of community empowerment carried out by the Bandung City Culture and Tourism Office to be steps taken in preparing the management of tourism destinations in Bandung City in 2020 through special allocation funds. This study aims to identify the tourist attractions in the Braga Tourism Village which is integrated in the Braga Village with a community empowerment approach. The method used is a survey method with a qualitative approach through community empowerment techniques. Obstacles that occur from destination management in Bandung City, especially those that occur in Kampung Wisata Braga, from the results of research, namely management, facilities and regulations are obstacles that occur in development. The results of the development of tourism destination governance that can be developed in the Braga Tourism Village by integrating the tourism potential in Braga Village in the form of the main activities that exist, namely traveling around visiting cultural heritage and getting to know history.

Keywords : Tourism Village; Community Development; Tourism Development

\section{A. PENDAhUluan}

Kota Bandung merupakan ibu kota dari Provinsi Jawa Barat yang menjadi salah satu destinasi kunjungan wisatawan di Provinsi Jawa Barat yang terletak pada $107^{\circ} 36^{\prime}$ Bujur Timur dan $6^{\circ} 55^{\prime}$ Lintang Selatan. Secara administratif Kota Bandung berbatasan dengan beberapa daerah kabupaten/kota lainnya, yaitu: Utara berbatasan dengan Kabupaten Bandung dan Kabupaten Bandung Barat, Barat berbatasan Kota Cimahi, Timur berbatasan dengan Kabupaten Bandung, dan Selatan berbatasan dengan Kabupaten Bandung. Kota Bandung sendiri berada di ketinggian 700 di atas permukaan laut (dpl) memiliki luas $167,31 \mathrm{~km}^{2}$ dengan terbagi dari 30 Kecamatan dari 151 Kelurahan yang tersebar, suhu Kota Bandung rata - rata yaitu $23,71{ }^{\circ} \mathrm{C}$ dengan jumlah penduduk yang ada sebanyak 2.507.888 jiwa (BPS Kota Bandung, 2020). Perkembangan pariwisata di Kota Bandung sangat pesat karena Bandung sendiri menjadi pintu masuk wisata di Jawa Barat melalui Bandar Udara Husain Sastranegara. Pengembangan pariwisata di Kota Bandung dapat terlihat dalam Rencana Pembangunan Jangka Menengah Daerah (RPJMD) Kota Bandung Tahun 2018-2023 dalam potensi pengembangan wilayah yang ada, pengembangan kawasan wisata buatan direncanakan 
dengan mengembangkan aspek-aspek, sebagai berikut: (1) Mempertahankan kawasan dan bangunan bersejarah, (3) Pengembangan obyek wisata di wilayah Bandung Timur, (4) Mempertahankan obyek wisata pendidikan dan wisata budaya kota, (5) Pengembangan sarana konferensi ke arah wilayah Bandung Timur, (6) Pengendalian dan pembatasan kegiatan hiburan di lokasi sekitar kegiatan peribadatan, pendidikan, dan perumahan.

Proses mewujudkan pengembangan potensi wilayah yang ada Dinas Kebudayaan dan Pariwisata Kota Bandung miliki visi kepariwisataan yang tertulis dalam Perda No. 1 Tahun 2013 tentang RIPPARKOT Bandung 2012-2025, yaitu Kota Bandung sebagai destinasi pariwisata perkotaan yang kreatif, berbudaya, \& berakhlak mulia. Implementasi dari visi tersebut dengan mengembangkan aksesibilitas, fasilitas dan daya tarik wisata dengan berlandaskan kreatif, berbudaya dan berakhlak mulia. Salah satu fokus utama dalam pengembangan tata kelola destinasi di Kota Bandung dengan mengembangkan kampung wisata yang ada di perkotaan. Seiring dengan perkembangan terminologi dari kampung wisata tidak lagi identik dengan kawasan pedesaan namun sekarang sudah menjalar di daerah perkotaan. Kampung selalu bermakna sebagai pemukiman yang sudah melekat dalam terminologi masyarakat, namun tidak hanya sebutan berupa nama tempat bermukim sekelompok komunitas atau masyarakat pada terminologi yang berkembang sekarang kampung menjadi kategori sosial yang membedakan komunitas pada kategori ruang dan fisik (Prasojo et al., 2020). Salah satunya terminologi Kampung Wisata yang berada di perkotaan yang diartikan sebagai Kampung Wisata yang dikembangkan sebagai langkah membangun ekonomi masyarakat pada sektor pariwisata dalam wilayah dan memberikan dampak berganda (multiplier effect) untuk pertumbuhan sektor kehidupan (Dewanti \& Soeprapto, 2019). Oleh sebab itu, pemerintah Kota Bandung mencanangkan kampung kreatif dalam 30 kecamatan di Kota Bandung. Pengembangan pariwisata yang ada dalam tata kelola destinasi kampung wisata di Kota Bandung diharapkan dapat dibentuk sebagai kampung wisata tematik dengan atribut penting yang mengintegrasikan potensi wisata yang ada di sekitar kampung wisata. Salah satunya, Kampung Wisata yang diusung dalam pengembangan dari 30 Kecamatan di Kota Bandung yaitu Kampung Wisata Braga melalui pendekatan pemberdayaan masyarakat.

Pola pembangunan pariwisata yang berkelanjutan membutuhkan peran masyarakat menjadi penting dalam proses keberlangsungan kawasan (Kartika et al., 2019). Berdasarkan konsep pemberdayaan masyarakat dalam pembangunan kepariwisataan maka upaya terhadap pemberdayaan masyarakat melalui kepariwisataan pada hakikatnya harus diarahkan pada beberapa hal sebagai, berikut: (1) Meningkatnya kapasitas, peran dan inisiatif masyarakat pembangunan kepariwisataan,
Meningkatnya posisi dan kualitas keterlibatan/partisipasi masyarakat, (3) Meningkatnya nilai manfaat positif pembangunan kepariwisataan bagi kesejahteraan ekonomi masyarakat, (4) Meningkatnya kemampuan masyarakat dalam melakukan perjalanan wisata (Sunaryo, 2013: 219; Cbt et al., 2018). Sementara itu Adiyoso (2009) dalam Dewi et al., (2013) menegaskan bahwa keterlibatan partisipasi masyarakat merupakan komponen terpenting dalam upaya pertumbuhan kemandirian dan proses pemberdayaan. Proses pemberdayaan masyarakat dalam pengembangan pariwisata merupakan salah satu langkah dalam pendekatan bottom-up yang terjadi ketika penduduk lokal di suatu daerah terlibat aktif dalam proses pengambilan keputusan dan perencanaan kegiatan pariwisata, memberikan mereka rasa kepemilikan atas masa depan dan perkembangan mereka sendiri, serta mendorong dan memberdayakan mereka untuk lebih terlibat dalam kegiatan pariwisata (Agrusa, J., \& Albieri, G., 2011; Junaid, 2020).

Kampung Wisata Braga yang menjadi fokus pengembangan pariwisata dalam bentuk pemberdayaan masyarakat yang dilakukan Dinas Kebudayaan dan Pariwisata Kota Bandung menjadi langkah yang dilakukan dalam penyusunan tata kelola destinasi pariwisata di Kota Bandung pada tahun 2020 melalui dana alokasi khusus. Proses yang dilakukan Dinas Kebudayaan dan pariwisata Kota Bandung menempatkan fasilitator dalam pendampingan pariwisata untuk melakukan pemberdayaan masyarakat dalam tata kelola destinasi yang menghasilkan beberapa kondisi yang ada perihal keberadaan Kampung Wisata Braga yang tidak dapat berdiri sendiri maka perlu terintegrasi dengan daya tarik wisata lainnya, keberadaan Kampung Wisata Braga ini terletak di Kelurahan Braga yang menjadi keuntungan sebab Kelurahan Braga menjadi kawasan strategis pariwisata dalam Rencana Induk Pembangunan Kepariwisataan Daerah (RIPARDA) Kota Bandung tahun 2012 - 2025 sebagai kawasan pariwisata warisan budaya Alun-alun - Braga yang menjadi peluang yang dapat dimanfaatkan bagi masyarakat yang ada di sekitarnya. Aktivitas di kampung wisata sendiri perlu selalu terus ditingkatkan dengan kreativitas, inovasi dan produktif dalam menciptakan produk-produk baru maka keberlanjutan akan tetap terjaga (Afriza, 2020). Pemahaman masyarakat terkait potensi wisata yang ada masih minim sehingga kawasan Braga hanya menjadi tempat hiburan dan kuliner semata saja dan tidak terintegrasinya Kampung Wisata Braga dengan daya tarik yang ada di Kelurahan Braga.

Kota Bandung telah memiliki Kampung Kreatif yang pada dasarnya memiliki arah pengembangan kepada Kampung Wisata yang di rasa sudah siap dalam menerima wisatawan dengan berlandaskan dengan keberadaan surat keterangan penetapan sebagai Kampung Wisata yaitu Kampung wisata Dago Pojok, Kampung Wisata Cibunut, Kampung 
Wisata Braga dan Kampung Wisata Cigadung. Keempat Kampung Wisata tersebut memiliki keunikan dan tema yang berbeda seperti Kampung Wisata Cigadung yang baru ditetapkan pada tahun 2020 oleh Dinas Kebudayaan dan Pariwisata Kota Bandung sebagai Kampung wisata dengan tema wisata kreatif yang menyuguhkan ikon kreatif di kawasan tersebut seperti kuliner, fesyen, kerajinan dan batik. Adapun, Kampung Wisata Cibunut sebagai Kampung Kreatif yang ramah lingkungan yang dahulunya merupakan kawasan pemukiman kumuh menjadi kampung yang mengkampanyekan gerakan diet plastik yang sekarang dijadikan kampung percontohan bebas plastik (Riyanti et al., 2020). Kampung Wisata Dago Pojok menjadi wisata kreatif berdasarkan kajian bahwa Kampung Wisata Dago Pojok terdapat lima kriteria sebagai wisata kreatif di antaranya wisatawan menjadi bagian dalam pengembangan destinasi, terdapat pengalaman otentik kepada wisatawan, terdapat pembelajaran dengan partisipasi, interaktif, informal, tidak berciri massal, dan berhubungan bersama masyarakat lokal (Chairunisa., 2012; Dewanti \& Soeprapto, 2019). Kampung Wisata Braga sendiri merupakan pemukiman kumuh termasuk ke dalam kawasan kumuh berat (Wihadanto et al., 2017). Namun, sekarang Kampung Wisata Braga didorong menjadi Kampung Kreatif untuk memanfaatkan ruang kekumuhan tersebut sebagai tempat yang bermanfaat bagi masyarakat dengan mengangkat keunikan dari Kampung Wisata tersebut yang menjadi potensi yang dapat dimanfaatkan oleh masyarakat.

Maka dari itu, penelitian ini bertujuan untuk mengidentifikasi daya tarik wisata yang berada di Kampung Wisata Braga yang terintegrasi di Kelurahan Braga dengan pendekatan pemberdayaan masyarakat. Identifikasi ini diharapkan dapat menjadi arahan pengembangan tata kelola destinasi di Kota Bandung dan dapat memberikan gambaran berupa hambatan juga kebutuhan penelitian selanjutnya untuk memperkaya kajian pariwisata secara akademisi di Kampung Wisata Braga.

\section{B. METODE PENELITIAN}

Peneliti menggunakan metode survei dengan melakukan pendekatan kualitatif. Menurut Sugiyono (2010) dalam Jamalina \& Wardani (2017), penelitian kualitatif yaitu metode dengan berlandaskan kepada filsafat postpositivisme yang digunakan dalam meneliti kondisi objek alamiah (sebagai lawan dari eksperimen) dan menyatakan peneliti merupakan sebagai instrumen kunci, pengambilan sampel sumber data dilakukan purposive, teknik pengumpulan dengan gabungan (triangulasi), proses analisis data memiliki induktif/kualitatif, lalu hasil dari penelitian lebih menekan pada makna daripada generalisasi. Adapun menurut Wardiyanta (2006) dalam Asy'ari (2018), menjelaskan metode survei merupakan metode yang menggunakan survei-survei keadaan, survei pendapat, atau survei interpretasi, semuanya dapat digunakan dengan melakukan wawancara pribadi, melalui surat, telepon, atau melalui bantuan alat elktronik lainnya dan melakukan FGD (focus group disccusion). Sementara itu, penelitian kualitatif memiliki ciri yaitu sumber data diperoleh secara langsung yang menjadi data situasi alami dan peneliti menjadi instrumen kunci dalam penelitian dan bersifat deskriptif, menekan pada proses yang menjadi sebuah makna ketimbang hasil lalu analisis data bersifat induktif (Asy'ari, 2018).

Pengembangan dilakukan dengan melihat unsur pariwisata dari $5 \mathrm{~A}$ dan $2 \mathrm{P}$ sebagai unsur yang akan menguatkan terbentuknya kampung wisata kearah mandiri dan berkelanjutan, unsur pariwisata yang di identifikasi di antaranya berupa atraksi, aktivitas, fasilitas, aksesibilitas, akomodasi dan unsur lainya yang harus diperhatikan yaitu pengelolanya dan pemberdayaan masyarakat (Afriza, 2020). Dengan melihat jenis wisata Alam, buaya dan kriya (hasil karya manusia) dengan mengembangkan aktivitasnya di antaranya (1) Apa yang bisa dilihat oleh wisatawan, (2) apa yang bisa dilakukan oleh wisatawan, (3) Apa yang bisa dibawa oleh wisatawan, (4) apa yang bisa dipelajari oleh wisatawan, (5) apa yang membuat kenangan pada kedatangannya bagi wisatawan dan (6) Apa yang membuat wisatawan lama tinggal. Bermula dari identifikasi dan pemenuhan unsur hingga melakukan berbagai aktivitas di kampung wisata dilanjut dengan menjelajahi kemungkinankemungkinan potensi kegiatan yang lain.

Pendekatan pemberdayaan masyarakat dalam pengembangan pariwisata yang dilakukan penelitian ini menggunakan 7D dengan menerapkan suatu model pengembangan apresiatif yang memusatkan perhatian secara khusus terhadap partisipasi masyarakat menurut Dhamotharan (2009) dalam Kartika et al., (2019) yaitu Developing relation (Mengembangkan hubungan), Discovering capacities (Menemukan kapasitas), Dreaming of community future (Membangun cita-cita masyarakat), Directions of community actions (Arah tindakan masyarakat), Designing community actions (Merancang tindakan masyarakat), Delivering Planned Activities (Melaksanakan kegiatan), dan Documenting Outputs, Outcomes and Learning (Mendokumentasikan hasil). Penelitian ini hanya mengambil 2 unsur pendekatan pemberdayaan yaitu Developing relation (Mengembangkan hubungan) yang dilakukan dengan membangun hubungan untuk membentuk kepercayaan bersama anggota kelompok masyarakat dan bersama masyarakat dengan pihak luar (fasilitator, narasumber, pejabat pemerintah dan lain-lain) dalam proses mewujudkan hal tersebut perlu disediakan waktu bagi semua orang untuk mengenal tentang diri masing-masing sehingga dapat menghargai kemampuan masing-masing dalam memberikan kontribusi untuk pembangunan masyarakat dan melalui unsur pendekatan Discovering capacities (Menemukan kapasitas) sebagai upaya masyarakat mencoba menemukan dan memahami tentang yang 
mereka miliki, kekuatan dan kelemahan mereka, dan potensi sumber daya mereka yang dapat digunakan (Kartika et al., 2019).

Penggunaan metode survei dengan pendekatan kualitatif dalam penelitian dilakukan untuk pengumpulan data 5A2P (atraksi, aktivitas, amenitas, aksesibilitas, akomodasi, pengeloaan dan pemberdayaan) dengan menggunakan survei keadaan secara langsung dan survei pendapat menurut partisipan melalui wawancara secara langsung juga melalui focus group discussion (FGD). Proses pengumpulan data dilakukan selama 30 hari dengan melakukan pemberdayaan secara langsung melalui unsur pemberdayaan yaitu Developing relation (Mengembangkan hubungan) dan Discovering capacities (Menemukan kapasitas) dengan pelibatan partisipasi masyarakat dalam melakukan survei di dalam kawasan untuk mengetahui potensi wisata dalam merancang atribut penting dalam Kampung Wisata. Data yang terkumpul di analisis dengan triangulasi (gabungan) secara deskriptif yang hasilnya menjadi pengembangan tata kelola destinasi pariwisata dalam penelitian ini.

\section{HASIL DAN PEMBAHASAN}

\section{Proses Pemberdayaan Masyarakat}

Proses pemberdayaan masyarakat Kampung Wisata Braga dengan melakukan tahapan mengembankan hubungan (developing relation), Pendampingan tata kelola pariwisata dalam proses ini yang dilakukan peneliti dengan menggali presepsi terhadap para pihak (steakeholder) yang terkait dalam pengembangan pariwisata dan menggali potensi wisata yang ada di Kampung Wisata Braga. Proses pengembangan hubungan dilakukan dengan pertemuan beberapa tokoh yang ada di Kelurahan

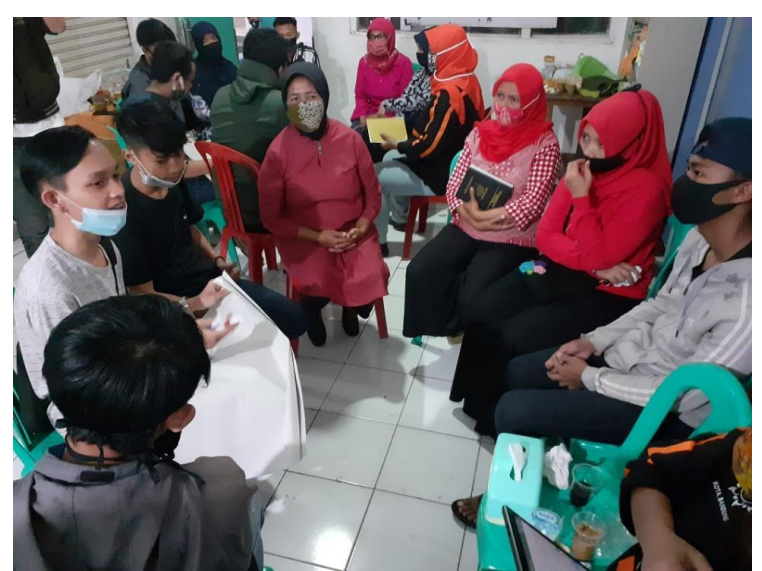

Gambar 1 Proses Focus Group Disccusion (FGD) Sumber : Foto Peneliti, 2020

Braga dan Kampung Wisata Braga menghasilkan isu-isu yang berkembang dalam pengembangan tata kelola destinasi Kampung Wisata Braga, di antaranya (1) masyarakat masih belum paham akan fungsi dan manfaat dari pariwisata, (2) belum terdapat serangkaian perjalanan yang menghubungkan potensi wisata di Kelurahan Braga,
(3) Karang Taruna dan Ibu PKK (Pemberdayaan Kesejahteraan Keluarga) di kawasan Braga berpotensi untuk diberdayakan dalam pengembangan pariwisata, (4) terdapatnya tumpang tindih kebijakan yang berada di Kampung Wisata Braga yang menghambat pengembangan pariwisata, (5) antusias masyarakat cukup tinggi untuk terlibat dalam pengembangan pariwisata, (6) pengelolaan wisata Kampung Wisata Braga yang belum berjalan secara efektif.

Adapun, pengumpulan data yang dilakukan dengan focus group disccusion (FGD) dilakukan bersama masyarakat yang bersangkutan dalam penggalian potensi wisata Kampung Wisata Braga didapat beberapa potensi yang di tuliskan di antaranya : Teras Braga sebagai ikon wisata, working space, kegiatan melukis (terdapat satu penggiat lukis di Rukun Warga (RW) 8), seni budaya calung (dahulu sering dilakukan oleh karang taruna karena ada salah satu penggiat yang mengajarkan dan tinggal di Rukun Warga (RW) 8), terdapat 3 bangunan bersejarah yang masih ada (2 menjadi toko dan 1 di huni oleh masyarakat yang lokasinya dekat working space), terdapat sejarah dari masyarakat afrika yang tinggal di Braga (keturunannya masih hidup dan bertempat tinggal di Rukun Warga (RW) 8) dan keinginan dari masyarakat Kampung Braga dalam pengembangan kaulinan bahela (permainan zaman dahulu) di pelataran working space sebagai aktivitas yang dapat dilakukan oleh wisatawan. Potensi pendukung lainnya Terdapat 10 mesin jahit dari CSR WIKA yang akan di pergunakan oleh ibu PKK (Pendidikan Kesejahteraan Keluarga) untuk memproduksi masker dan baju kolonial yang dijual sebagai cendera mata atau digunakan dalam kegiatan pengembangan pariwisata di Kampung Wisata Braga.

Dalam mengembangkan hubungan pada pemberdayaan masyarakat temuan dari pengumpulan data persepsi masyarakat bahwa antusias masyarakat dirasa sangat besar dan perlu bantuan untuk mendorong pengembangan secara lebih intensif dari pemerintah untuk menggerkaan atau membina program untuk masyarakat dalam pengembangan tata kelola destinasi wisata Braga khususnya Kampung Wisata Braga dan pelatihan dasar kepariwisatan perlu dilakukan untuk membentuk pemahaman pariwisata di Kawasan Braga.

Proses pemberdayaan masyarakat dalam tahapan menentukan kapasitas (discovering capacities) dalam tahapan ini membutuhkan waktu cukup panjang dilakukan peneliti dengan menghabiskan waktu selama 3 minggu dengan mencoba mengidentifikasi potensi daya tarik wisata secara langsung di Kelurahan Braga khususnya Kampung Wisata Braga bersama masyarakat. Kekuatan yang terdapat di Kampung wisata Braga dari temuan yang diungkapkan masyarakat berupa kawasan Kampung Wisata Braga berada dalam kawasan strategis dengan dekatnya Kampung ini dari jalan Braga yang mayoritas wisatawan beraktivitas di jalan tersebut, namun hambatan yang ada terkait pengelolaan yang 
tidak berjalan efektif sehingga kunjungan wisatawan belum tertuju ke Kampung Wisata atau petunjuk area yang masih belum ada. Peneliti mendapatkan temuan dalam potensi yang terdapat dari setiap Rukun Warga (RW) di Kelurahan Braga yang dapat diintegrasikan sebagai supporting produk (produk pendukung) dalam pengembangan Kampung Wisata Braga. Pada dasarnya daya tarik wisata yang terdapat di Kampung Wisata Braga tidak memberikan dampak secara langsung terhadap Kampung Wisata Braga khususnya masyarakat Rukun Warga (RW) 8 sebab wisatawan yang datang ke Kelurahan Braga lebih banyak menghabiskan waktu di Jalan Braga atau pun daya tarik di sekitarnya seperti Museum Asia-Afrika, Museum Banceuy dan lainnya sehingga wisatawan tidak beraktivitas dalam Kampung Wisata Braga secara langsung, faktor yang ada tersebut membuat daya tarik di sekitar Kampung Wisata Braga dapat di jadikan sebagai produk pendukung dalam pengembangan pariwisata untuk meningkatkan kunjungan ke Kampung Wisata Braga.

\section{Identifikasi Potensi Kampung Wisata Braga}

Kampung Wisata Braga di tetapkan dalam keputusan wali Kota Bandung no. 145/Kep. 1458DisBudPar/2018 sebagai Kampung Wisata kreatif, warisan budaya dan sejarah yang terletak di Kelurahan Braga. Kampung Wisata Braga berada di Rukun Warga (RW) 8 Kelurahan Braga. Kelurahan Braga sendiri dari hasil analisis memiliki potensi di antaranya secara geografis Kelurahan Braga berada di pusat Kota Bandung, yang sebagian besar memiliki potensi khususnya di bidang/sektor ekonomi dengan menjamurnya pertokoan, pusat perbelanjaan, hotel/ penginapan, restoran, serta bentuk Industri lainnya, hal ini dapat menyokong laju dan pergerakan ekonomi warga Braga khususnya menunjang keberadaan Kampung Wisata Braga. Selain di bidang/sektor ekonomi, potensi lain yaitu pada sektor pariwisata seperti wilayah Asia - Afrika, dengan cagar Budaya Gedung Merdeka yang sering menjadi tujuan wisatawan lokal maupun asing dan keunikan Jalan Braga, yang kerap menjadi spot/tempat berfoto. Potensi lainnya, muncul dari warga Braga sendiri, yang sebagian kecil mempunyai jiwa wirausaha yang cukup tinggi dan potensi Kewirausahaan warga di Kelurahan Braga cukup beragam, di antaranya usaha di bidang kuliner, kerajinan tangan, air brush, sampai usaha Rajutan.

Atraksi, atraksi yang didapat dari hasil analisis dilihat dari peta sebaran daya tarik wisata (Gambar 2) yang menunjang keberlangsungan pengembangan tata kelola destinasi di Kampung Wisata Braga terdapat 20 daya tarik sebagai atribut penting dalam potensi Kampung Wisata Braga yang tersebar di Kelurahan Braga yang secara garis besar terkait atraksi yang ada mengangkat sisi budaya dan sejarah. Kreativitas masyarakat pun menjadi salah satu keunggulan di Kampung Wisata Braga ini terlihat dari mural dan produk yang di hasilkan dari ibu-ibu PKK (Pemberdayaan Kesejahteraan Keluarga) di antaranya boneka, masker, makanan kemasan, dan lain-lain. Kampung Wisata Braga yang terletak di Rukun Warga (RW) 8 tidak bisa berdiri sendiri karena pada hakikatnya pariwisata akan berkembang ketika setiap komponen dalam satu kawasan saling

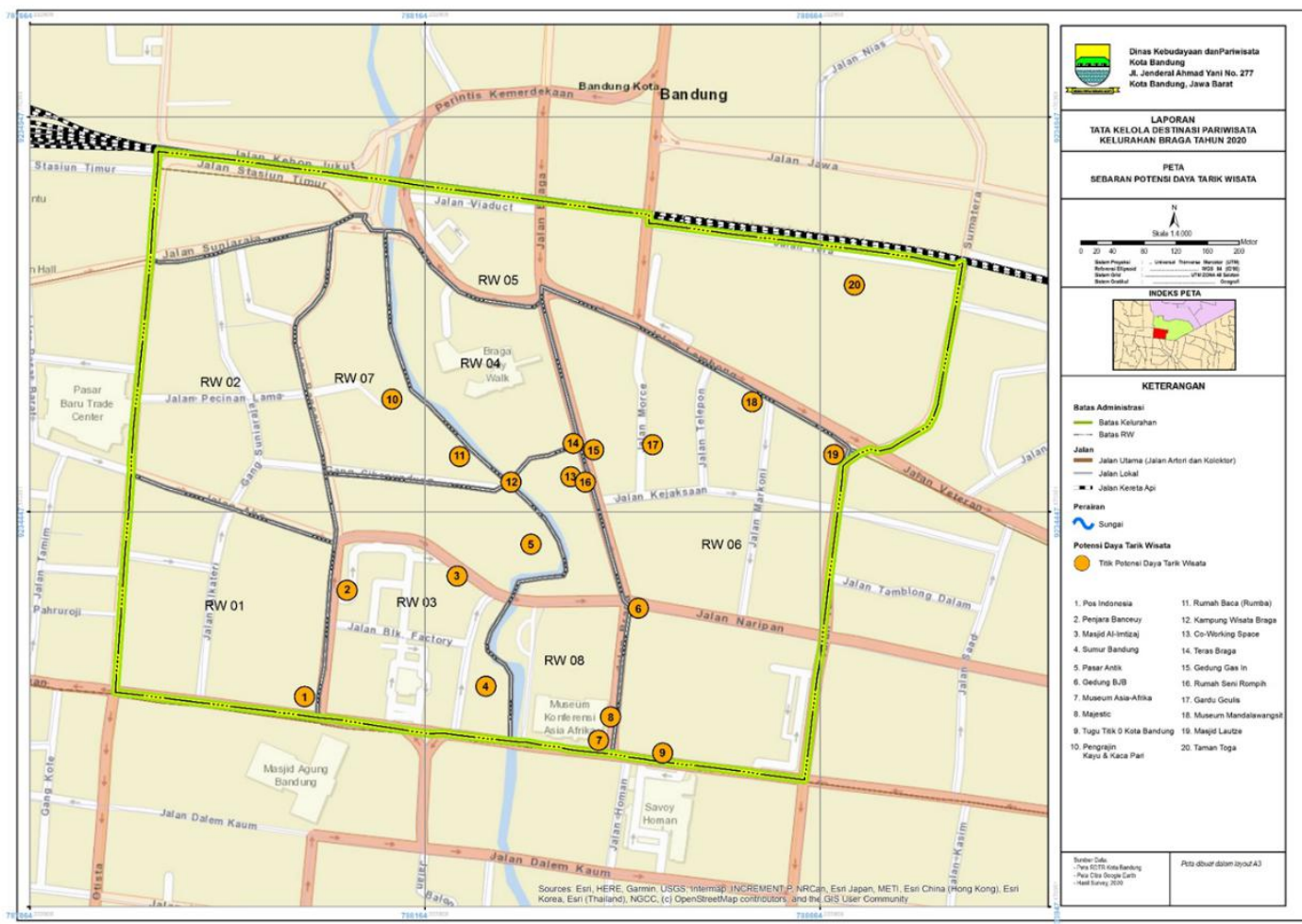

Gambar 2 Peta Sebaran Daya Tarik Wisata di Kelurahan Braga

Sumber : hasil olahan data peneliti, 2020 
berkolaborasi. Kelurahan Braga memiliki 8 Rukun Warga (RW) dari keseluruhan rukun warga yang ada semua memiliki potensi yang berbeda dan dapat dikembangkan menjadi satu pola perjalanan. Dari hasil identifikasi bersama masyarakat dominasi potensi daya tarik wisata yang ada kebanyakan berada di Rukun Warga 8, 6, dan 3 yang menjadi fokus dalam pengembangan pola perjalanan wisata untuk menghubungkan atraksi yang ada karena memiliki cukup banyak daya tarik wisata yang terdapat di Rukun Warga tersebut. Namun, rukun warga yang tidak menjadi fokus dalam pengembangan menjadi salah satu kawasan penunjang sebab kebanyakan fasilitas umum dan fasilitas pariwisata ada terletak di lima Rukun Warga $(1,2,4,5,7)$ yang ada.

Aktivitas, Aktivitas wisatawan yang sering berkunjung dilakukan dari hasil identifikasi yaitu berfoto dengan berkunjung di pemukiman yang berbentuk gang atau lorong kecil di perkotaan dan bangunan berarsitektur tua yang menjadi tempat berfoto secara perorangan atau tanpa menggunakan paket wisata. Aktivitas wisata yang dapat dikembangkan dalam Kampung Wisata Braga dari hasil analisis menyebutkan bahwa Kampung Wisata Braga tidak dapat berdiri sendiri sehingga harus terintegrasi dengan daya tarik wisata yang telah di sebutkan sebelumnya dengan mengarahkan aktivitas ngubek kampung dengan mengitari daya tarik wisata yang tersebar di Kelurahan Braga. Kampung Wisata Braga yang berada di permukiman yang sudah identik dengan mural yang berada di tembok pemukiman menjadi daya tarik tersendiri yang menjadi tempat penunjang aktivitas berfoto untuk wisatawan dan keberadaan seniman lukis dapat dijadikan salah satu kegiatan wisata yang berada di Kampung Wisata Braga yang pada akhirnya kegiatan tersebut dapat disabungkan dengan daya tarik wisata yang berada di sekitar kampung dengan menjelajahi jalur kampung untuk sampai ke daya tarik wisata yang ada.

Amenitas atau fasilitas, Fasilitas yang berada di Kampung Wisata Braga cukup memadai karena letak dari Kampung Wisata Braga berada di tengah kota membuat fasilitas umum dan fasilitas pariwisata cukup memadai terlihat dari tersebarnya hotel/penginapan dan restoran di Rukun Warga (RW) 8 yaitu penginapan Gasinn dan di antaranya restoran atau rumah makan yaitu Teras Braga yang baru saja dibuka sebagai fasilitas penunjang dalam keberadaan Kampung Wisata Braga. Fasilitas penunjang lainnya seperti petunjuk arah (signage) yang mengarahkan keberadaan Kampung Wisata Braga masih tidak ada begitu pun tourism information sebagai sarana ruang informasi untuk memberikan arah daya tarik wisata masih tidak ada sehingga wisatawan yang berkunjung ke Kelurahan Braga tidak mengetahui bahwa di kawasan tersebut terdapat Kampung Wisata.

Aksesibilitas, Akses untuk mencapai Kampung Wisata Braga dapat dilalui oleh kendaraan bermotor dan mobil maupun bus yang notabene parkir dilakukan di jalan Braga. Untuk menyusuri pemukiman wisatawan perlu melakukan jalan kaki karena Kampung wisata Braga memiliki bentuk pemukiman yang memiliki akses jalan gang. Kampung Wisata Braga sendiri dapat dilalui dari jenis jalan utama (arteri dan kolektor) dan jalan lokal membuat peluang bagi Kampung Wisata Braga dari segi akses yang mudah dilalui. Akses dari Bandara Husein Sastranegara menuju Kampung Wisata Braga kurang lebih menempuh waktu 22 menit dengan jarak tempuh $8,5 \mathrm{Km}$. Aksesibilitas peluang yang sangat besar bagi pengembangan pariwisata namun hasil dari jejak pendapat yang dilakukan dengan masyarakat bahwa masyarakat menyadari itu semua yang menjadi keresahan yaitu lahan parkir yang sudah cukup minim dan terbatas menjadi ancaman yang perlu terselesaikan.

Pengelolaan dan pemberdayaan masyarakat, pemberdayaan masyarakat yang telah disampaikan di atas bahwa kegiatan lanjutan dalam pemberdayaan masyarakat perlu dilakukan lanjutan atau lebih intensif untuk membentuk visi bersama masyarakat dalam pengelolaan pariwisata. Dari hasil identifikasi didapat bahwa keberadaan Rukun Warga (RW) 8 yang di tetapkan sebagai Kampung Wisata Braga tidak bersamaan dengan keberadaan SK pengelolaan Kampung wisata Braga yang menyebabkan ketimpangan dalam proses pengelolaan di Kampung Wisata Braga. Antusias masyarakat Rukun Warga (RW) 8 yang cukup partisipasi dapat di dorong dalam pengelolaan pariwisata dan keberadaan kelompok penggerak pariwisata (KOMPEPAR), GALUR dan komunitas lainnya dapat di bersinergi dalam pengelolaan pariwisata di Kelurahan Braga.

\section{E. SIMPULAN}

Kampung Braga memiliki keunikan dan ikon yang kuat melekat dengan Kota Bandung yang dikenal dengan Bandung Heritage yang memiliki sejarah dan dikenal sebagai kota konferensi Asia Afrika. Dalam arah pengembangan tata kelola destinasi pariwisata yang dapat dikembangkan di Kampung Wisata Braga yaitu "Ngubek Kampung" sebagai sarana mengintegrasi potensi wisata yang ada di Kelurahan Braga dengan kegiatan utama yang ada yaitu berkeliling mengunjungi warisan budaya dan mengenal sejarah. Atraksi utama yang diberikan adalah berkeliling di Kampung Wisata Braga dengan mengunjungi Co-Working Space dan Teras Braga. Sasaran wisatawan yang dapat di dorong yaitu para backpacker yang berkunjung ke Braga, di mana mereka membutuhkan partner (pasangan) untuk menjelajahi kampung di Braga karena dari hasil pembahasan di atas didapat bahwa kecenderungan orang tidak ingin untuk membeli paket di Braga sebab banyak wisatawan yang berpikiran masih bisa dan mampu untuk melakukan wisata sendiri tanpa perlu menggunakan paket wisata. Ini menjadi salah satu penelitian yang dapat dilakukan selanjutnya dengan mengidentifikasi tipologi wisatawan yang berkunjung ke Kampung Wisata Braga sehingga 
dapat dilihat dari segmen dan harapan yang dapat dikembangkan dalam kawasan Kampung Wisata Braga.

Hambatan yang terjadi dari tata kelola destinasi di Kota Bandung khususnya yang terjadi di Kampung Wisata Braga dari hasil penelitian yang ada terlihat pada pengelolaan, amenitas (fasilitas) dan regulasi menjadi hambatan yang terjadi. Pengelolaan pariwisata di Kampung Wisata Braga menjadi hambatan dalam tata kelola destinasi sehingga perlu menjejaki pengelolaan yang terhubung satu sama lain dalam kawasan, amenitas atau fasilitas yang ada masih kurang terlebih pada papan petunjuk arah dan interpretasi yang menggambarkan Kampung Wisata Braga, dan regulasi antar para pihak secara formal dan tertulis yang ada dalam pengembangan tata kelola destinasi perlu diciptakan dalam membentuk kolaborasi. Pengembangan Kampung Wisata tidak dapat berdiri masing-masing salah satu kelemahan yang paling berasa kurang kuatnya sinergi dan kolaborasi lintas sektor. Adapun, hambatan penelitian ini yaitu batas waktu dalam melakukan pemberdayaan masyarakat yang dilakukan dalam situasi pandemi sehingga pendekatan pemberdayaan masyarakat terbatas karena waktu dan ruang sehingga diharapkan untuk peneliti selanjutnya dapat melakukan pemberdayaan masyarakat dalam tata kelola destinasi dengan jarak waktu lebih lama.

\section{DAFTAR PUSTAKA}

Afriza, L. (2020). PENDAMPINGAN DESA / KAMPUNG WISATA SEBAGAI DESTINASI.

Asy'ari, R. (2018). KONSEP PENGEMBANGAN DESA LIANG NDARA SEBAGAI DESA WISATA DI PROVINSI NUSA TENGGARA TIMUR KABUPATEN MANGGARAI BARAT Universitas Pendidikan Indonesia | repository.upi.edu | perpustakaan.upi.edu. 2012, 22-46.

BPS Kota Bandung. (2020). Kota bandung Dalam Angka 2020. Badan Pusat Statistik Kota Bandung, 1-392.

Cbt, T., Carang, D., Kecamatan, W., \& Kabupaten, W. (2018). Jurnal Ilmiah Administrasi Publik ( JIAP ) Strategi Pengembangan Potensi Pariwisata Melalui Pendekatan Community Based. 4(4), 363-368.

Dewanti, I. S., \& Soeprapto, A. (2019). PENGEMBANGAN PARIWISATA PERKOTAAN BERBASIS KOMUNITAS : Pendahuluan. 17, 58-66.
Dewi, M. H. U., Fandeli, C., \& Baiquni, M. (2013). Pengembangan Desa Wisata Berbasis Partisipasi Masyarakat Lokal Di Desa Wisata Jatiluwih Tabanan, Bali. Kawistara, 3(2), 117226.

Jamalina, I. A., \& Wardani, D. T. K. (2017). Strategi Pengembangan Ekowisata Melalui Konsep Community Based Tourism (Cbt) Dan Manfaat Sosial Dan Ekonomi Bagi Masyarakat Di Desa Wisata Nglanggeran, Patuk, Gunung Kidul. Jurnal Ekonomi \& Studi Pembangunan, 18(1), 71-85. https://doi.org/10.18196/jesp.18.1.4008

Junaid, I. (2020). Implementasi Pariwisata Berkelanjutan di Pulau Maratua, Kabupaten Berau, Kalimantan Timur. Jurnal Pariwisata Terapan, 3(2), 110. https://doi.org/10.22146/jpt.46518

Kartika, T., Afriza, L., \& Fajri, K. (2019). Pemberdayaan Masyarakat Di Desa Wisata Cibuntu Kabupaten Kuningan Provinsi Jawa Barat. Journal of Indonesian Tourism, Hospitality and Recreation, 2(1), 11-24. https://doi.org/10.17509/jithor.v2i1.16427

Peraturan Daerah Kota Bandung Nomor 01 Tahun 2013. Rencana Induk Pembangunan Kepariwisataan Daerah Tahun 2012 - 2025

Peraturan Daerah Kota Bandung Nomor Tahun 2019. Rencana Pembangunan Jangka Menengah Daerah Tahun 2018-2023

Prasojo, Z. H., Arifin, M., Abdullah, I., Islam, A., Pontianak, N., Ilmu, F., Politik, I., Mulawarman, U., Antropologi, D., Ilmu, F., Mada, U. G., \& Indonesia, Y. (2020). Dislokasi Identitas Agama dan Budaya Perkotaan: Perkembangan Kampung Wisata di Kota Yogyakarta. 4(1), 17-34. https://doi.org/10.21580/jsw.2020.4.1.5545

Riyanti, A., Afriza, L., Ilmu, T., \& Pariwisata, E. (2020). Kemenarikan dalam Pemberdayaan Masyarakat di Kampung Wisata Cibunut Kota Bandung. 21(2), 159-177.

Wihadanto, A., Barus, B., Achsani, N. A., \& Bratakusumah, D. S. (2017). Analisis Karakteristik dan Penilaian Tingkat Kekumuhan Kawasan Permukiman 'Kampung Braga' - Kota Bandung. Journal of Regional and Rural Development Planning, 1(2), 132144.

https://doi.org/10.29244/jp2wd.2017.1.2.132144 